\title{
Article \\ Climatic and Biological Factors Related with Goat Grazing Management in the Arid Grassland of the Coquimbo Region (Northern Chile)
}

\author{
Daniel Patón (D)
}

Citation: Patón, D. Climatic and Biological Factors Related with Goat Grazing Management in the Arid Grassland of the Coquimbo Region (Northern Chile). Ecologies 2021, 2, 345-365. https://doi.org/10.3390/ ecologies 2040020

Academic Editor: José Ramón Arévalo Sierra

Received: 8 September 2021

Accepted: 20 October 2021

Published: 21 October 2021

Publisher's Note: MDPI stays neutral with regard to jurisdictional claims in published maps and institutional affiliations.

Copyright: (C) 2021 by the author. Licensee MDPI, Basel, Switzerland. This article is an open access article distributed under the terms and conditions of the Creative Commons Attribution (CC BY) license (https:/ / creativecommons.org/licenses/by/ $4.0 /)$.
Ecology Unit, Faculty of Science, The University of Extremadura, Av. de Elvas, s/n, 06071 Badajoz, Spain; d.paton.d@gmail.com

\begin{abstract}
Background: Desertification is one of the most important environmental impacts around the world. In the semiarid grassland of North of Chile, overgrazing has deep effects on arid lands and consequently on its economy and social development. It is necessary to conduct very detailed studies to determine how the climate, the botanical composition and the grazing system affects this process; (2) Methods: In this paper, we have determined the effect on arid grasslands of three goat managements: exclusions, continuous and deferred grazing on forage biomass, richness, BergerParker's dominance and Shannon's diversity. This study was developed in Las Cardas Range Station (CEALC) of the University of Chile in the Coquimbo region. The effect of annual and seasonal rainfall on biomass, diversity, richness and dominance parameters was determined; (3) Results: Allochthonous, endemic and native species showed significant changes both for seasonal and annual precipitation. In contrast, the grazing system only affected dominance and biomass of native and endemic species. Deferred grazing was the only management system that increased overall biomass productivity, especially on the best forage plant species. Exclusions showed a positive influence on more endangered species, which were the most vulnerable to goat overgrazing; (4) Conclusions: In consequence, we proposed a network of areas under deferred grazing combined with exclusions. This strategy can increase simultaneously forage productivity, grassland conservation and preservation of associated resources as hunting and wildlife tourism. Moreover, this strategy of range management will allow the sustainability of community of farmers in one of the poorest and most desertified areas in South America.
\end{abstract}

Keywords: range management; overgrazing; desert communities; native grasslands; invasive plants

\section{Introduction}

Recent research indicates that $41 \%$ of the Earth's land surface and within this, $45 \%$ of the agricultural areas are at serious risk of desertification [1]. This represents 10-20\% of the world's arid zones [2]. It is expected that by the end of the century, the area of drylands in the world will have increased by 11 to 23\% [3]. In South America, this process is especially problematic, covering the $31 \%$ of the territory [4]. In many arid rangelands the main economic activity is livestock farming on natural vegetation [5]. When in these fragile environments, the arid forage resources are not managed properly so overgrazing occurs [6]. In drylands under Mediterranean climate, such as the North of Chile, desertification is especially intense, increasing annually from 0 to $1 \%$ due to the combination of overgrazing, pruning, forest fires and climate change $[7,8]$. This is undoubtedly Chile's biggest problem, affecting 2/3 of the country's territory [9].

Desertification effects are affecting not only natural processes but also social development of rural areas, income level, education resources and migration of local population [9]. These processes are especially problematic in certain sectors of the population, such as small farmers and ranchers, who only receive income from their agricultural activity [10]. As a result, this group enters a vicious circle of poverty that makes them dependent on their 
own subsistence conditions on the one hand, and prevents them from escaping from this underdevelopment on the other [11]. This forces us to invest even more in new technologies that facilitate the maintenance of an economically viable agricultural population that does not have alternatives. Recently, the use of solar energy, the implementation of new ecosystem services [12] or the appearance of new biotechnologies, specific to arid zones, point to more optimistic scenarios for the rural development [13]. Especially relevant is the project of the Great Green Wall (GGW) developed by many countries to combat desertification in the Sahel [14]. Broadly speaking, the project consists of developing a strip of native (NT) shrubs and trees with sustainable silvopastoral managements. Many strategies are being developed to combat the loss of diversity in arid zones. Recovering native plant species is one of the most important because they are plants that show unique adaptations to water stress, with pharmacologically useful chemical components and act as nursing plants, contributing to the creation of ecological islands of biodiversity [2]. Due to the low population density of arid zones, the loss of genetic resources is much faster than in other areas.

In regard to natural effects of desertification in North Chile, one of the strongest is the reduction in the level of aquifers [15]. These aquifers depend especially on the high precipitation events produced by ENSO (El Niño Southern Oscillation) [16]. It is due to these events that a savanna of arid shrub vegetation with very deep root systems is maintained in these areas of Chile. The deep root systems of these arid Chilean woody species contribute to soil fixation, preventing desertification [17]. Moreover, these species can be excellent nursery plants for small trees that form the savanna type forest typical of many arid environments [14]. For these reasons, different strategies have been designed for the introduction of shrub species to combat desertification in Northern Chile [18]. Moreover, many bushes act as nursing plants of local grasslands buffering the effect of climate change [19]. Consequently, if woody vegetation disappears in the area, there is a very rapid acceleration of desertification (a typical catastrophic cascading process) with a consequent reduction in biodiversity [2]. This decline affects all trophic levels such as grasslands, small mammals, insects and predators [20]. Therefore, to maintain an appropriate level of shrub cover and a good farming management is absolutely necessary to avoid desertification in arid areas [21]. This can be done by regulating the carrying capacity of grasslands because other environmental restoration strategies, such as planting native shrubs in large areas, have a high economic cost of implementation and success is not always guaranteed [14].

Traditionally, livestock management in Northern Chile is based on free-ranging goats under continuous grazing [22]. Different studies suggest that this is not the best management system for the conservation of arid rangelands [7,23]. In fact, this goat grazing method reduces the abundance of the best forage native species that usually are the worst adapted to overgrazing [24]. Secondly, an increment in invasive and unpalatable grasses, forbs and shrubs is produced by an excess of livestock pressure [25]. Moreover, these alien species are the most resistant to ruminants due to its higher reproductive rates and lower palatability [26]. All these changes in grassland composition are usually associated to a marked reduction of nutritional value [27] and diversity [28] of rangelands. This reduction in diversity is at the expense of native species [29]. Moreover, invasive species can cause significant changes in the carbon and water cycles at the ecosystem level [30]. Consequently, continuous grazing significantly reduces the biomass (B) of arid steppes, as well as their photosynthetic activity [31]. Nor can we ignore the alterations on nutrient recycling and especially on carbon sequestration in areas under continuous grazing compared to protected areas [32]. These multiple effects of continuous grazing are being tested in many arid rangelands around the world with similar results [6-33]. 
In Northern Chile, the loss of autochthonous (AU) species by overgrazing probably began in the 15th century [34], during the Spanish Conquest period, but it only has been registered since 18th century [35]. During the conquest, the seeds of allochthonous (AL) grassland species were transported by small ruminants (sheep and goats) introduced by the Spanish conquerors [36]. Today, AL species are dominant whereas the relict vegetation only survive in very isolated areas [37]. This relationship between inefficient pastoral models from the colonial past and current degradation has been observed in other parts of the world [38].

In the present paper, we analyze the effect of seasonality, rainfall and grazing management system on Shannon's diversity $\left(\mathrm{H}^{\prime}\right)$, specific richness $(\mathrm{S})$, Berger-Parker's dominance (d), total biomass (B) and productivity of AL, native (NT) and endemic (EN) species in North Chile. Few studies on Chilean arid rangelands have been conducted with the level of annual, seasonal and spatial replication of this study. Moreover, our study is based on the analysis of a high number of permanent transects that allow a clear analysis of botanical changes across time. In consequence, our methodology is especially useful in areas that are very variable in environmental conditions, such as Northern Chile, because it reduces statistical noise, permitting obtaining valuable conclusions. Moreover, we will study the environmental factors implied in the growing reduction of EN and NT vegetation that is other collateral problem of desertification process. Therefore, the aim of this paper is weighting the relative influence of climate, invasion of AL species and overgrazing on arid rangelands of the IV Region of Chile, proposing solutions for one of the most desertified areas in the world.

\section{Experimental Section}

\subsection{Sampling Area}

Grassland sampling was done in Las Cardas Range Station (CEALC), an experimental area belonging to the Faculty of Agronomy of the University of Chile (Figure 1). CEALC is located in the North of IV Region of Chile, near the city of Coquimbo (between $30^{\circ} 13^{\prime}$ and $30^{\circ} 19^{\prime}$ latitude South, and $71^{\circ} 13^{\prime} 30^{\prime \prime}$ and $71^{\circ} 19^{\prime}$ longitude West). The average altitude of the study area was $260 \mathrm{~m}$. Annual average temperature from 1977 to 2020 was $14.8^{\circ} \mathrm{C}$. The average monthly temperature varies between $11^{\circ} \mathrm{C}$ in July and $19{ }^{\circ} \mathrm{C}$ in January due to the Humboldt Current [39]. Annual rainfall in the same period was $109 \mathrm{~mm}$ but with a marked interannual variability [40]. The $63 \%$ of precipitation was concentrated during the winter. The years with more intense rainfall levels were associated to "El Niño" Southern Oscillation (ENSO) events. In contrast, summer drought was due to Mesoscale Convective Systems (MCSs) [41]. The two wettest months in the area were June (18\% of annual rainfall) and July (44\%). Despite the scarce annual rainfall in the area, the water deficit did not surpass $900 \mathrm{~mm} \cdot$ year $^{-1}$ due to the influence of coastal fogs which produced a relative humidity of $71 \%$ in January and $78 \%$ in July. This effect affected to our study area but decreased to few $\mathrm{km}$ away from the coast [42] and it markedly influenced the botanic composition [43]. The soil type is an Orthid Aridisol formed by coluvial-alluvial material derived from granitic batholite of the coastal mountains [44]. The $0-60 \mathrm{~cm}$ of depth is a sandy clay loam and soil over $60 \mathrm{~cm}$ has a higher clay content. Under $60 \mathrm{~cm}$ of depth an extremely hard layer of mineral deposits is present. This limits the flux of nutrients and consequently the arid agriculture in the area. Soil $\mathrm{pH}$ is close to neutral [45]. 


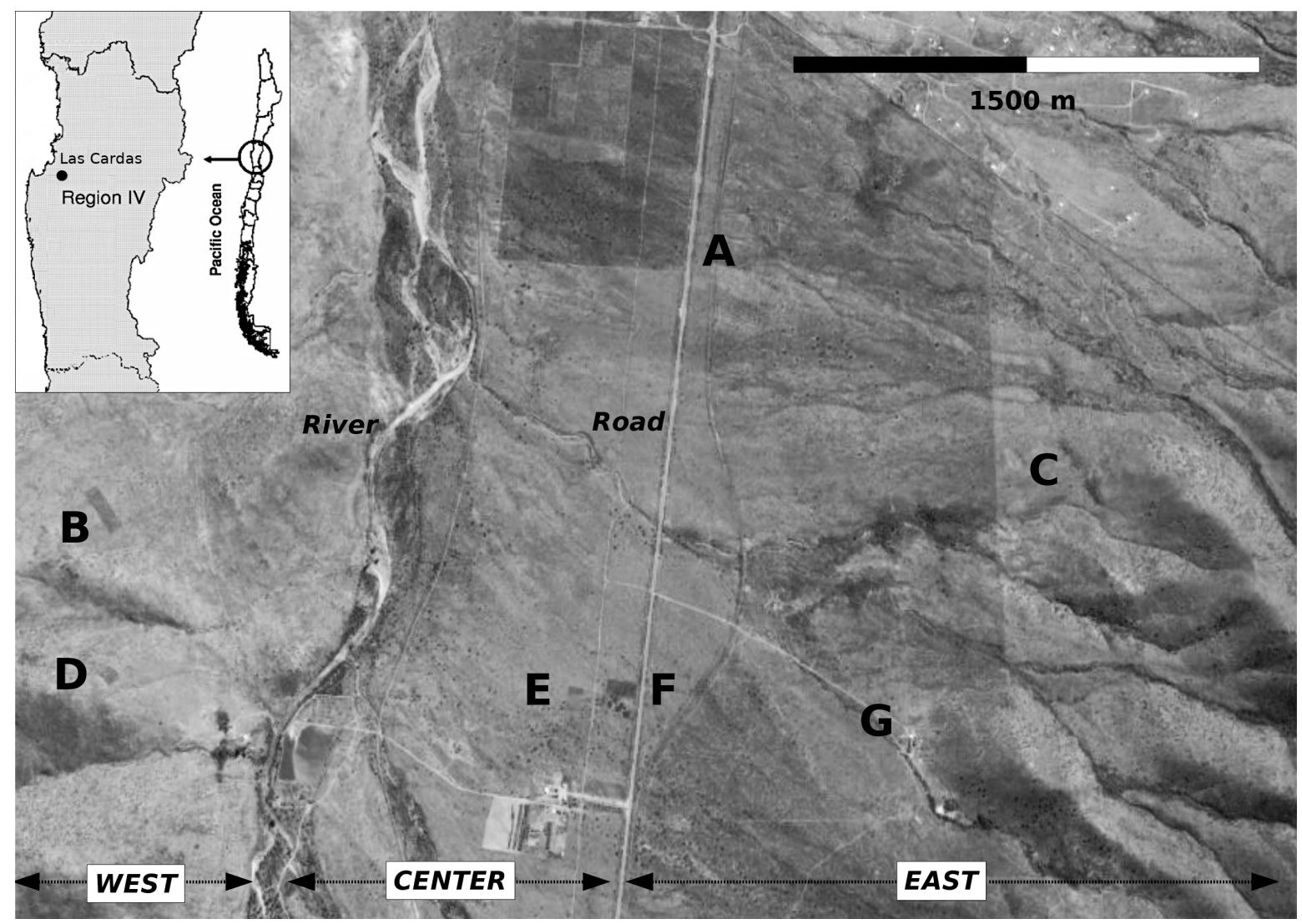

Figure 1. Location of the exclusions to grazing at Las Cardas Range Station (CEALC) (IV Region of Chile). The river and the road limit the three independent zones where the exclusions (A-G) described in detail in the section of Supplementary Materials are located.

The shrub community in the area comprised the species Flourensia thurifera (Molina) DC, Heliotropium stenophyllum Hook et Arn, Gutierrezia resinosa Hook et Arn, Porliera chilensis I.M. Johnst, Senna cummingii var. coquimbensis (Vogel) Irw. et Barneby and Adesmia microphylla Hook et Arn [23-46]. Grassland sampling was carried for 1983 to 1988, 1991 and 2002 (Figure 2). Sampling effort by season and years is shown in Table 1. Years were classified as wet or dry depending on if its rainfall levels were over or under $135 \mathrm{~mm}$. This was the average precipitation for the sampling period in the area. Grassland were grouped by its composition in autochthonous (AU) and allochthonous (AL) species (see Supplementary Materials). The first group was separated in native (NT) of Chile (distributed along III, IV, V and VI regions) (see Supplementary Materials) and endemic (EN) of the IV Region of Chile (see Supplementary Materials) following to [47]. NT and EN species showed marked differences in its ecological drought tolerance and vulnerability to overgrazing [48]. In this sense, EN species were better adapted to arid climate than NT species but both groups were vulnerable to overgrazing. Exactly the opposite happens with AL species that tolerate overgrazing and were less adapted to prolonged drought periods [7].

Table 1. Sampling effort (number of point-quadrats) across seasons and years in Las Cardas Range Station (CEALC) (Coquimbo, Chile).

\begin{tabular}{lcccccccc}
\hline Season & $\mathbf{1 9 8 3}$ & $\mathbf{1 9 8 4}$ & $\mathbf{1 9 8 5}$ & $\mathbf{1 9 8 6}$ & $\mathbf{1 9 8 7}$ & $\mathbf{1 9 8 8}$ & $\mathbf{1 9 9 1}$ & $\mathbf{2 0 0 2}$ \\
\hline Spring & 11 & 33 & 33 & 24 & 55 & 0 & 54 & 0 \\
\hline Autumn & 12 & 31 & 24 & 0 & 0 & 29 & 0 & 0 \\
\hline Winter & 11 & 33 & 33 & 33 & 56 & 56 & 0 & 115 \\
\hline
\end{tabular}



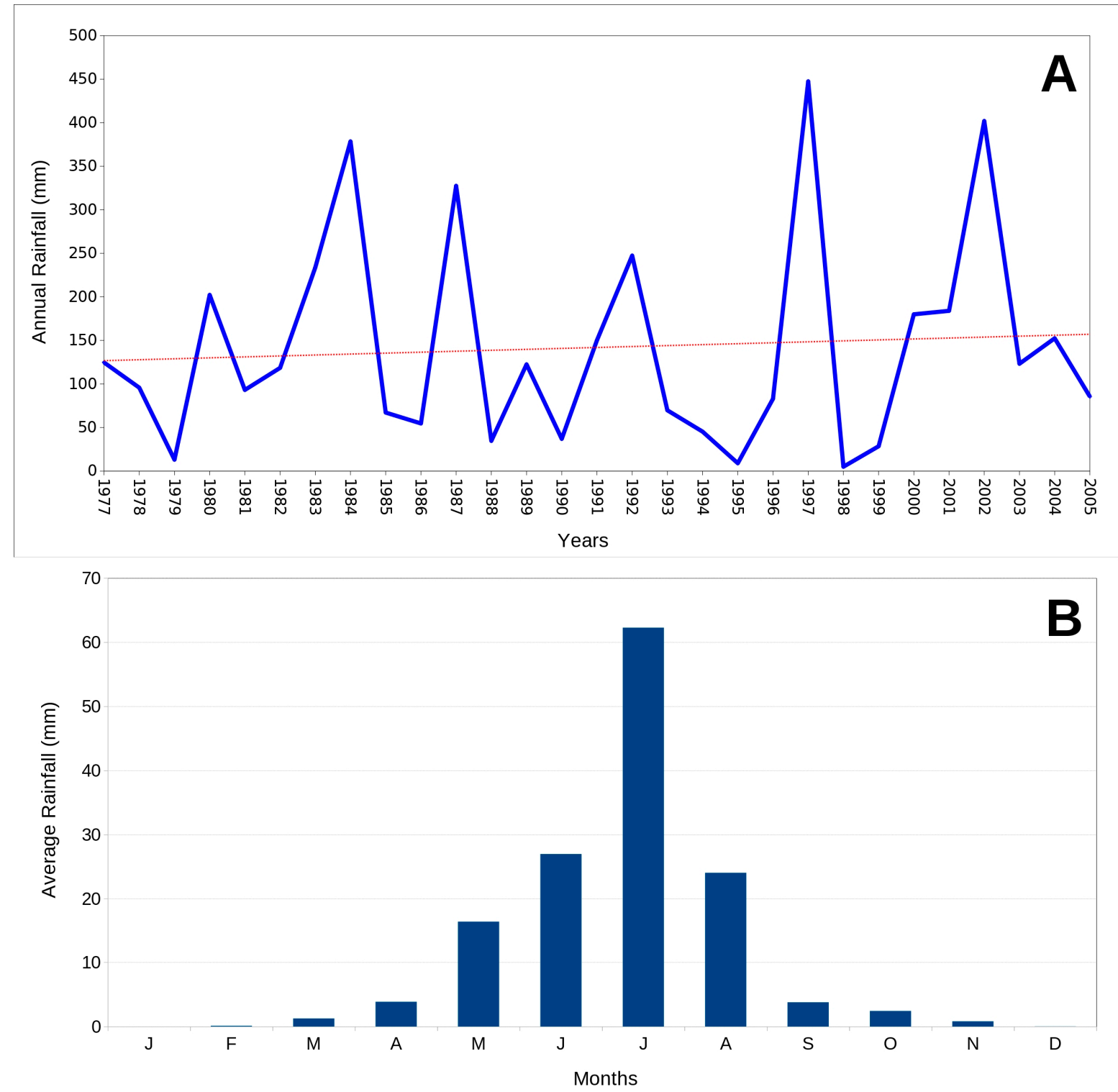

Figure 2. (A) Rainfall at Las Cardas Range Station (CEALC) from 1977 to 2005. Red dotted line (slope 1.08, not significantly difference from 1.00) is the linear regression of rainfall vs. year. (B) Average monthly rainfall in the same period.

\subsection{Management Systems}

The forage resources of CEALC have been managed by the principal experts in arid rangelands of the University of Chile since 1973. They have mainly applied continuous and deferred grazing systems. Continuous grazing is based on keeping animals in the field every day of the year. On the contrary, deferred grazing is based on letting the plants in a zone go to seed and grazing them immediately after until the plants are withered at the end of the grazing season. Only at night are the goats collected in stables. Continuous grazing was based on a constant stocking rate of 3 goat ha ${ }^{-1}$ [49]. Only two experimental herds with the same number of animals were considered in this study. Both flocks were completely separated by a road and therefore with no possibility of interactions between them (Figure 1). Consequently, both grazing areas were independent and can be considered as replicates. The two areas were under continuous grazing but inside them certain sectors were managed by deferred grazing [26]. These deferred areas were fenced and protected from grazing since late spring until autumn. Simultaneously, a set of 12 exclusions were distributed in the overall area of CEALC. These exclusions can be considered as independent replicates too (Figure 1). The goats did not pass between all these sampling 
areas by the presence of a river and the previous commented road that act as barriers. Both limits define three independent sampling areas in the West, Center and East of CEALC (Figure 1). As exclusions, we considered, not only the specifically constructed for this purpose, but the areas where the goats never grazed. As an example of the intense changes in botanical composition that were produced in these excluded areas, the aerial photographs showed a darker color that it was effect of a higher grass cover and shrub abundance (Figure 1). The time of creation, location, duration and size of these exclusions are shown in the section of Supplementary Materials. Exclusions allowed observing the effect of grazing protection on temporal changes in arid grasslands [2].

Goats belong to Criolla breed, a cross of local goats with Spanish Guadarrama breed [50]. Animals presented an average of two years old that corresponds to $35-40 \mathrm{~kg}$. Goats over 4 years were usually replaced by youngest due to the low milking productivity of this breed. Animals were under free ranging management and only were housed during the night to avoid the attack of desert foxes (Pseudalopex griseus Gray) or feral dogs. Goats were occasionally supplemented in summer with lucerne, grain, forage shrubs (Atriplex spp. and Opuntia spp.) and agriculture byproducts. Supplementation was only given during the driest periods, at evening after each grazing journey [22]. Consequently, this was a complement to the low nutritional value of natural vegetation that was the main food source [23]. In any case, this treatment was equally applied to both herds.

\subsection{Sampling Method}

This study covered a non-continuous period of 19 years and was seasonally highly replicated (Table 1). However, despite our data not being completely balanced, this was compensated by a high sampling size and the use of non-parametric methods that will be explained in detail after. In any case, these inhomogeneities in data are very frequent in many landscape studies that cover a wide temporal range and it can be easily solved with appropriate statistical procedures [51].

The three goat managements (exclusion, continuous and deferred grazing) have been maintained in CEALC since 1973. Sampling was distributed randomly inside the areas with homogeneous vegetation for each grazing treatment. We used point-quadrat transects to quantify plant abundances that consist in the measure of any contact on any green structure (leaves and green stems) of plants [52]. Total abundance of each plant species (phytovolume) was defined as its number of contacts along the transect [53]. This means that only the annual productivity was registered because woody contacts of shrubs and forbs were not measured. Previous methodological studies indicated that in arid areas the best point-quadrat dimension was $10 \mathrm{~m}$ of length with sampling points each $10 \mathrm{~cm}$ [54]. We took a special care for covering all the plant communities in the area. Total set of transects was 472 with 159 in continuous grazing areas, 165 in deferred grazing and 148 for exclusions.

Additionally, in each transect three $0.25 \mathrm{~m}^{2}(50 \times 50 \mathrm{~cm})$ squares were harvested and their average dry matter (DM) was the measure of phytomass (B) finally used [55]. This means $159 \times 3$ phytomass samples for continuous grazing, $165 \times 3$ in deferred grazing and $148 \times 3$ in exclusions. Biomass of AL, NT and EN species was calculated using a phytovolume-phytomass regression model specifically developed for these arid ecosystems. Biomass was calculated in kilograms per hectare $(\mathrm{kg} / \mathrm{ha})$. We followed the same methodology previously used in temperate Mediterranean [56] and tropical [57] rangelands.

\subsection{Statistical Analysis}

The factors defined in the analysis were management system (exclusion, continuous and deferred grazing), season (spring, autumn and winter) and type of the year (dry and wet) according to the average rainfall level that is $135 \mathrm{~mm}$ (Figure 2A).

Phytovolume of each species was used for the determination of Berger-Parker's dominance (d), Shannon's diversity index $\left(\mathrm{H}^{\prime}\right)$ and Richness (S) in each transect [58]. In order to compare these indexes between seasons, years and grazing treatments, we 
used a Hierarchical Partitioning (HP) test [59]. HP is an inferential analysis based on the testing of many multiple regressions with interaction terms and then, the explained independent variance of each factor is determined. The use of HP is increasing in the last decades because it was a substitute of parametric variance analysis and simultaneously complements multiple regression without the problems of multicollinearity, non-normality or heteroscedasticity of residues [60,61]. Moreover, HP method is robust to spatial and temporal dependence caused by sampling design [62]. HP can be used when sampling is not balanced or saying the same when there is absence of samples in certain combination of factors (Table 1) [63]. In consequence, HP analysis is perfect for the type of data that are commonly used in applied landscape ecology, specifically in conservation studies [64] where the sampling designs are very complex and despite this, we need to separate clearly the independent contribution of each environmental factor [65]. HP determines the percentage of total variance explained by each factor comparing their effects alone and in combination and the significance was calculated by a randomization test $[66,67]$.

Complementary to HP test, we carried out a non-parametric Spearman's rank correlation analysis for comparing the biomass between all the subsets of factors and groups of species (AL, NT and EN). Using this procedure, we detected if competence $(\varrho<0)$ or association $(\varrho>0)$ were significant between subsets. Finally, we compared the differences in B, d, S and H for the set of years using Dunn's post-hoc nonparametric test of variance. All the statistical analysis were calculated using R-package statistical environment [68].

\section{Results}

\subsection{Botanical Composition of Grassland Community}

Annual rainfall in CEALC is highly variable and winter dominant. However, the linear tendency across the sampling period was flat (Figure 2A). Associated to this variation in precipitation, strong changes in botanical composition were observed. Thus during the nine non-continuous years of sampling in the CEALC, we detected 129 species of vascular plants (distributed in 46 families) (see Supplementary Materials). In the three groups of vegetation (NT, EN and AL) defined by [47], we detected 37, 46 and 43 species, respectively. Poaceae and Asteraceae were the dominant families in AL ( 9 and 7, respectively) and NT (4 and 4, respectively) groups. EN species presented dominance of Asteraceae $(n=9)$ and Boraginaceae $(n=5)$ families. AL group of plants showed less botanical families $(n=16)$ than NT $(n=23)$ and EN $(n=24)$ groups. Consequently, EN and NT species of IV Region of Chile have a higher radiation in botanical families regard to species divergence. When the number of species were compared among life forms, the differences were clearer. In this sense, AL plants had a remarkable dominance of annual species of Poaceae $(n=34)$ compared with biennials $(n=3)$ and perennials $(n=10)$. In contrast, NT group presented less annual $(n=22)$ and more perennial $(n=13)$ species. This group even had two phanerophytes and one subfruticose taxon. Finally, EN group included the same number of annual species $(n=22)$ but an increase in perennial $(n=15)$, phanerophytes $(n=5)$ and subfruticoses $(n=4)$ life-forms. Consequently, the dominance of annual grasses was different in AL species $(77 \%)$ respect to NT $(60 \%)$ and EN (48\%) groups.

\subsection{Relationship of Rainfall, Season and Grazing System with Biomass and Botanical Composition}

The relative influence of rainfall, season and grazing systems was also studied in AL, EN and NT groups [47] (Table 2). Biomass of AL species was affected by rainfall and seasonality but not by grazing management (Table 2). Despite these results, non-significant slight changes can be observed in the AL species for the three different grazing treatments since 1983 (Figure 3). In contrast, NT species showed a significant decrease according to annual changes (Table 2) since 1983 in the three grazing managements (Figure 4). In the last year of sampling (2002), an increase in biomass of NT species was observed, especially in deferred grazing management (Figure 4). NT species also varied significantly in relation with seasonality and rainfall (Table 2). Finally, EN species showed significant changes in abundance respect to grazing systems, season and rainfall (Table 2 and Figure 5). The three 
groups of plants (AL, EN and NT) showed minimum values during 1988 (Figures 3-5), the driest year in the sampling period.

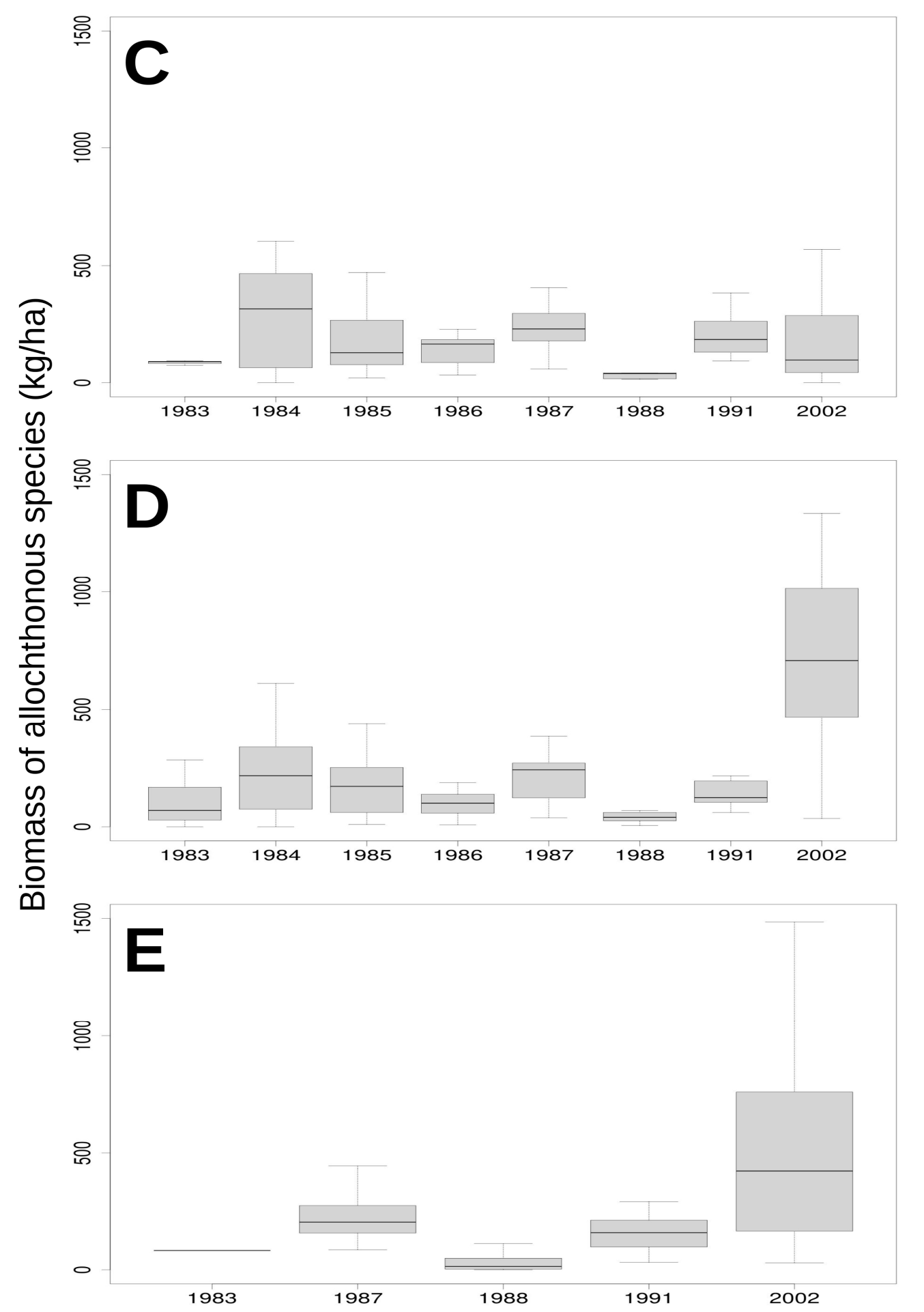

Figure 3. Annual changes in biomass of allochthonous species at Las Cardas Range Station (CEALC) under continuous (C), deferred (D) and exclusion (E) grazing treatments. 

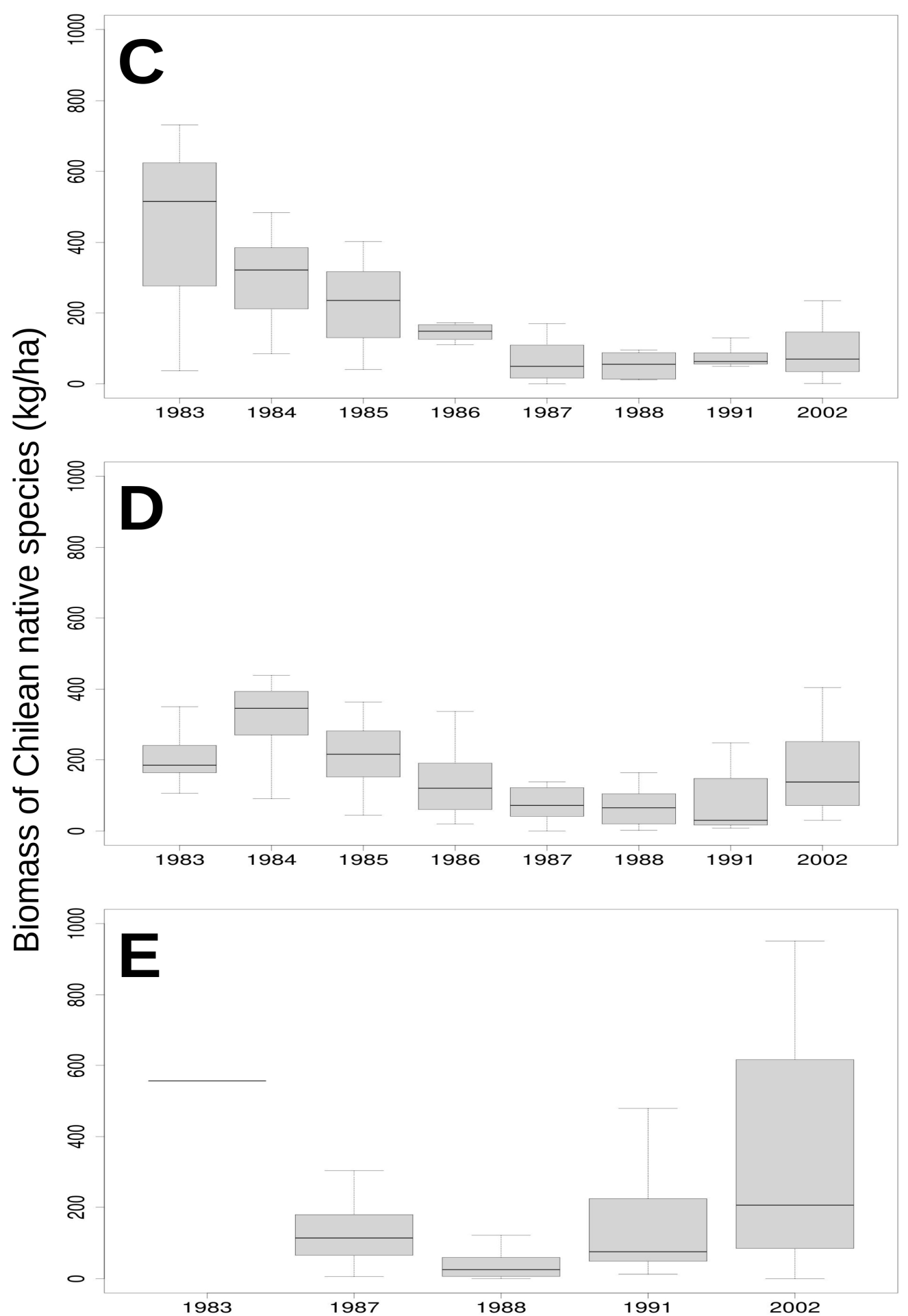

Figure 4. Annual changes in biomass of native of Chile species sampled at Las Cardas Range Station (CEALC) under continuous (C), deferred (D) and exclusion (E) grazing treatments. 


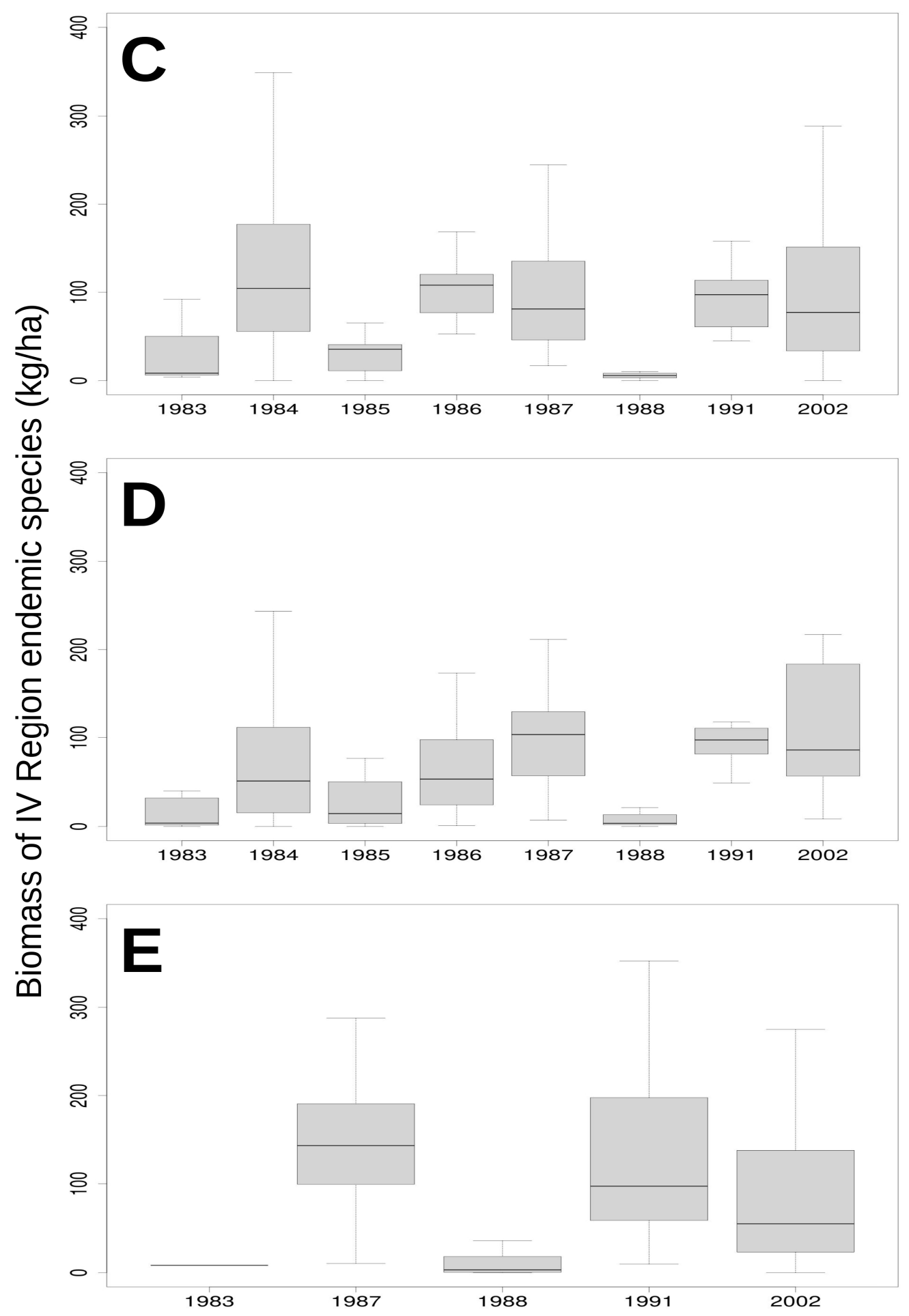

Figure 5. Annual changes in biomass of endemic species of IV Region of Chile sampled at Las Cardas Range Station (CEALC) under continuous (C), deferred (D) and exclusion (E) grazing treatments. 
Table 2. Percentage of total explained variance determined by Hierarchical Partition procedure. Z-scores of randomization test of hierarchical partitioning are shown between brackets. Asterisks represent the significance based on upper 0.95 confidence limit $(Z>=1.65)$. ns: non-significant differences.

\begin{tabular}{cccc}
\hline Parameter & Type of Year & Season & Grazing System \\
\hline Allochthonous species $\left(\mathrm{Kg} \mathrm{ha}^{-1}\right)$ & $19.89\left(5.83^{*}\right)$ & $73.07\left(10.27^{*}\right)$ & $7.05(0.07 \mathrm{~ns})$ \\
Native species $\left(\mathrm{Kg} \mathrm{ha}^{-1}\right)$ & $32.17\left(18.99^{*}\right)$ & $54.57\left(24.29^{*}\right)$ & $13.25\left(7.15^{*}\right)$ \\
Endemic species $\left(\mathrm{Kg} \mathrm{ha}^{-1}\right)$ & $35.53\left(13.16^{*}\right)$ & $31.94\left(8.60^{*}\right)$ & $32.54(7.85 *)$ \\
Richness (S) & $52.87\left(67.91^{*}\right)$ & $44.62(22.64 *)$ & $2.51(0.53 \mathrm{~ns})$ \\
Dominance $(\mathrm{d})$ & $22.04\left(9.91^{*}\right)$ & $70.42\left(25.31^{*}\right)$ & $7.54\left(1.92^{*}\right)$ \\
Diversity $\left(\mathrm{H}^{\prime}\right)$ & $42.92\left(31.17^{*}\right)$ & $54.49\left(22.80^{*}\right)$ & $2.59(0.19 \mathrm{~ns})$ \\
\hline
\end{tabular}

\subsection{Relationship of Rainfall, Season and Grazing System with Richness, Dominance and Diversity}

Rainfall and seasonality were related to $\mathrm{S}, \mathrm{H}^{\prime}$ and d changes for AL, NT and EN species (Table 2). Grazing system only affected to Berger-Parker's dominance in the three groups (Table 2). $\mathrm{S}$ and $\mathrm{H}^{\prime}$ did not show significant differences between grazing managements (Figures 6 and 7 and Table 2) and presented minimum values during 1988, the driest year registered in the sampling period (Figures 6-8) that showed an increment in Berger-Parker's dominance. The Spearman's correlations in biomass between plant groups gave additional information on symbiotic or competence relationships (Table 3). All the plant groups showed positive correlations but only significance in certain cases. Moreover, competence did not exist between AL, NT and EN species for rainfall, season and grazing managements. AL species showed positive significant correlations with NT $(\mathrm{r}=0.533 ; p<0.001)$ and EN $(\mathrm{r}=0.674 ; p<0.001)$ species during dry years. AL and EN species were positively correlated during spring $(\mathrm{r}=531 ; p<0.001)$ and fall $(\mathrm{r}=0.674$; $p<0.001)$. Contrary to these results, the interactions between EN and NT species were not so intense (Table 3). Only in dry years $(\mathrm{r}=0.372 ; p<0.001)$, in excluded areas $(\mathrm{r}=0.292$; $p<0.001)$ and during the winter season $(\mathrm{r}=0.279 ; p<0.001)$ can positive correlations be observed. Considering the whole set of positive correlations, we determined that the softest association was established between NT and EN species and secondly between NT and AL species. The highest positive association was registered between EN and AL species, the two groups that were further in origin, taxonomy, life forms and ecological adaptations.

Table 3. Spearman's correlations between the biomass of three groups of plants: allochthonous, native and endemic. ${ }^{*}$ : $p$-value $<0.05 ;{ }^{* *}: p$-value $<0.01 ;{ }^{* * *}: p$-value $<0.001$. ns: non-significant differences.

\begin{tabular}{cccc}
\hline Factor & Allochthonous-Native & Allochthonous-Endemic & Native-Endemic \\
\hline Continuous grazing & $0.085 \mathrm{~ns}$ & $0.291^{* * *}$ & $0.148 \mathrm{~ns}$ \\
Deferred grazing & $0.212^{* *}$ & $0.480^{* * *}$ & $0.148 \mathrm{~ns}$ \\
Exclusion to grazing & $0.256^{* *}$ & $0.255^{* *}$ & $0.292^{* *}$ \\
Wet years & $0.046 \mathrm{~ns}$ & $0.179^{* *}$ & $0.088 \mathrm{~ns}$ \\
Dry years & $0.533^{* * *}$ & $0.494^{* * *}$ & $0.372^{* * *}$ \\
Spring & $-0.022 \mathrm{~ns}$ & $0.531^{* * *}$ & $-0.039 \mathrm{~ns}$ \\
Fall & $0.089 \mathrm{~ns}$ & $0.674^{* * *}$ & $0.022 \mathrm{~ns}$ \\
Winter & $0.232^{* * *}$ & $0.137^{*}$ & $0.279^{* * *}$ \\
\hline
\end{tabular}



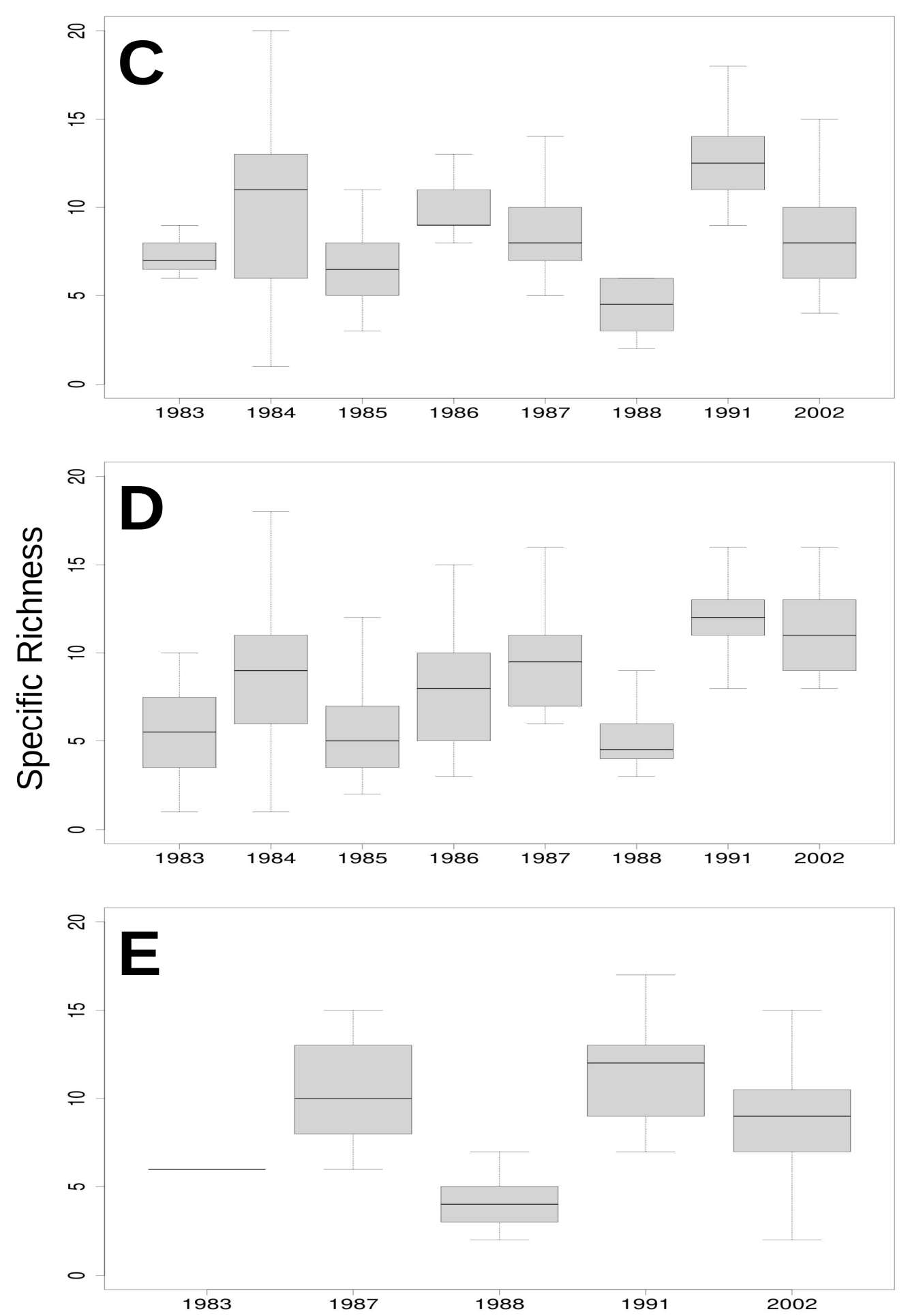

Figure 6. Changes in richness of species at Las Cardas Range Station (CEALC) in continuous (C), deferred (D) and exclusion (E) grazing treatments. 

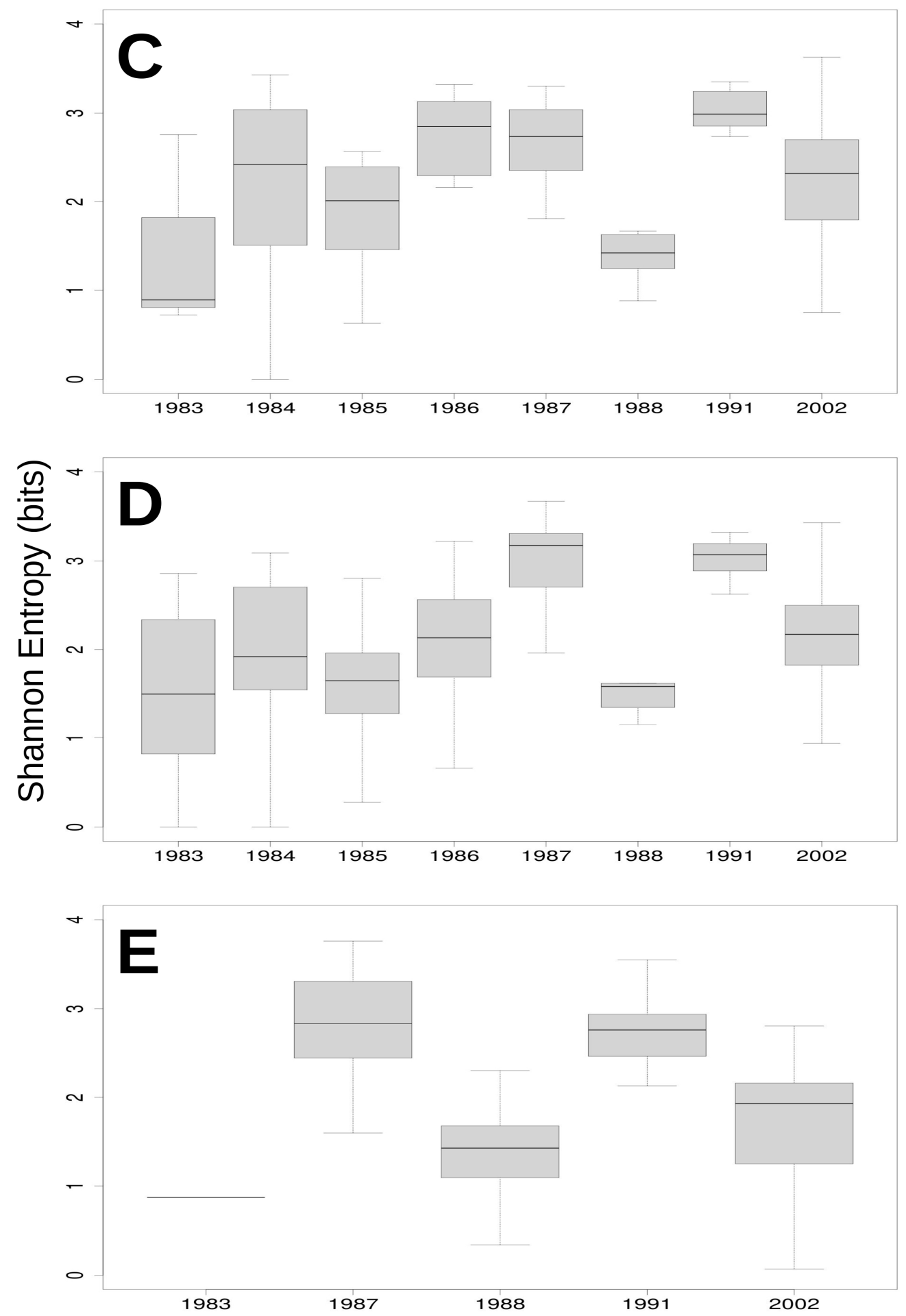

Figure 7. Changes in Shannon entropy at Las Cardas Range Station (CEALC) in continuous (C), deferred (D) and exclusion (E) grazing treatments. 

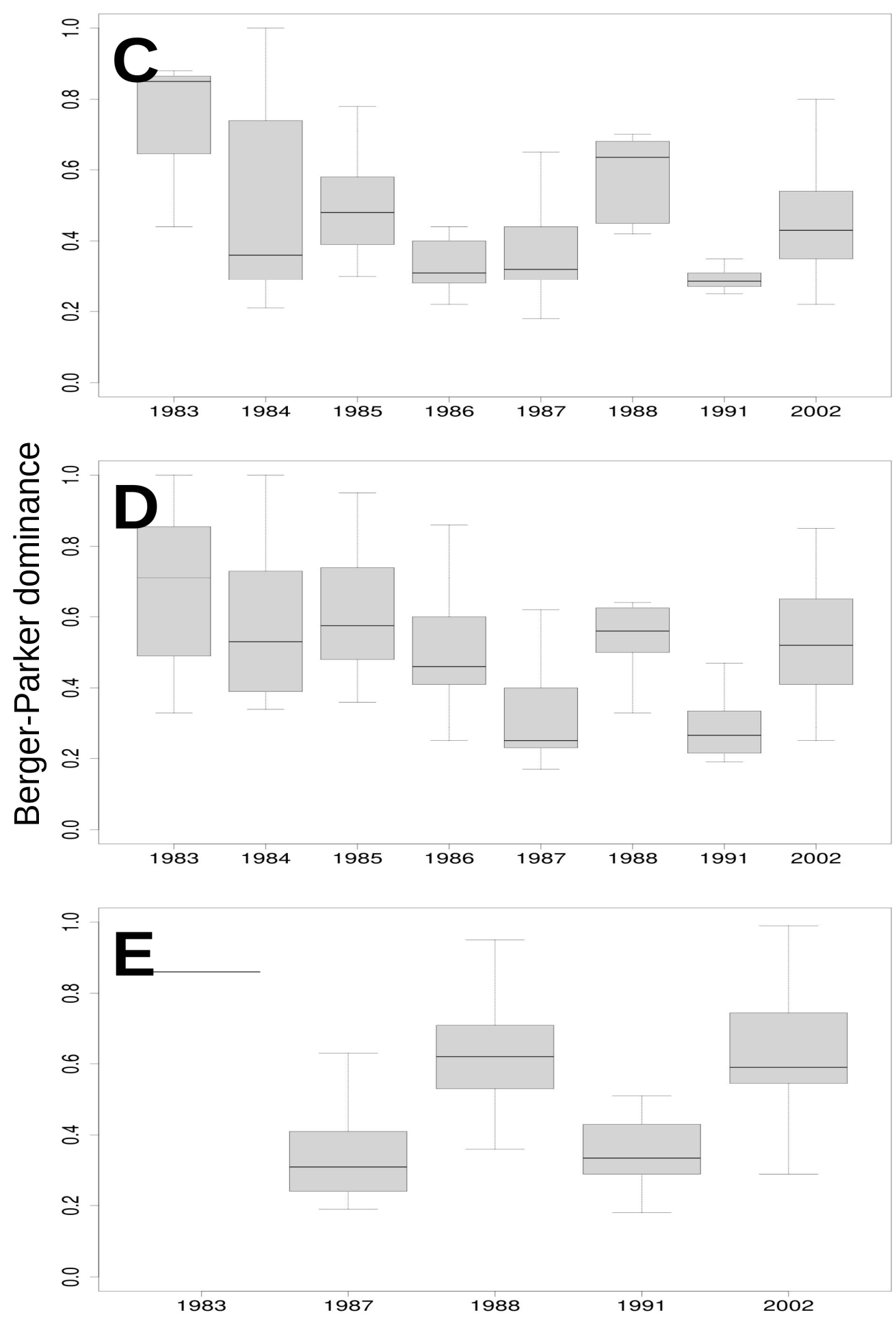

Figure 8. Changes in Berger-Parker dominance at Las Cardas Range Station (CEALC) in continuous (C), deferred (D) and exclusion (E) grazing treatments.

\subsection{Overall Differences between Grazing Treatments}

Dunn's test shows significant differences between grazing treatments for B, d, H and $S$ parameters (Figure 9). In the case of the Berger-Parker dominance index, the areas under deferred grazing show significantly higher values (Figure 9A). In terms of biomass, the exclusions are significantly more productive than the areas under continuous grazing (Figure 9B). The zones under deferred grazing show intermediate characteristics. On the other hand, excluded areas show higher species richness (S) than areas under deferred 
grazing (Figure 9C). Areas under continuous grazing show intermediate values. Finally, under deferred grazing, significant differences are observed in the lower $\mathrm{H}$ values with respect to the rest of the treatments, which are similar (Figure 9D).
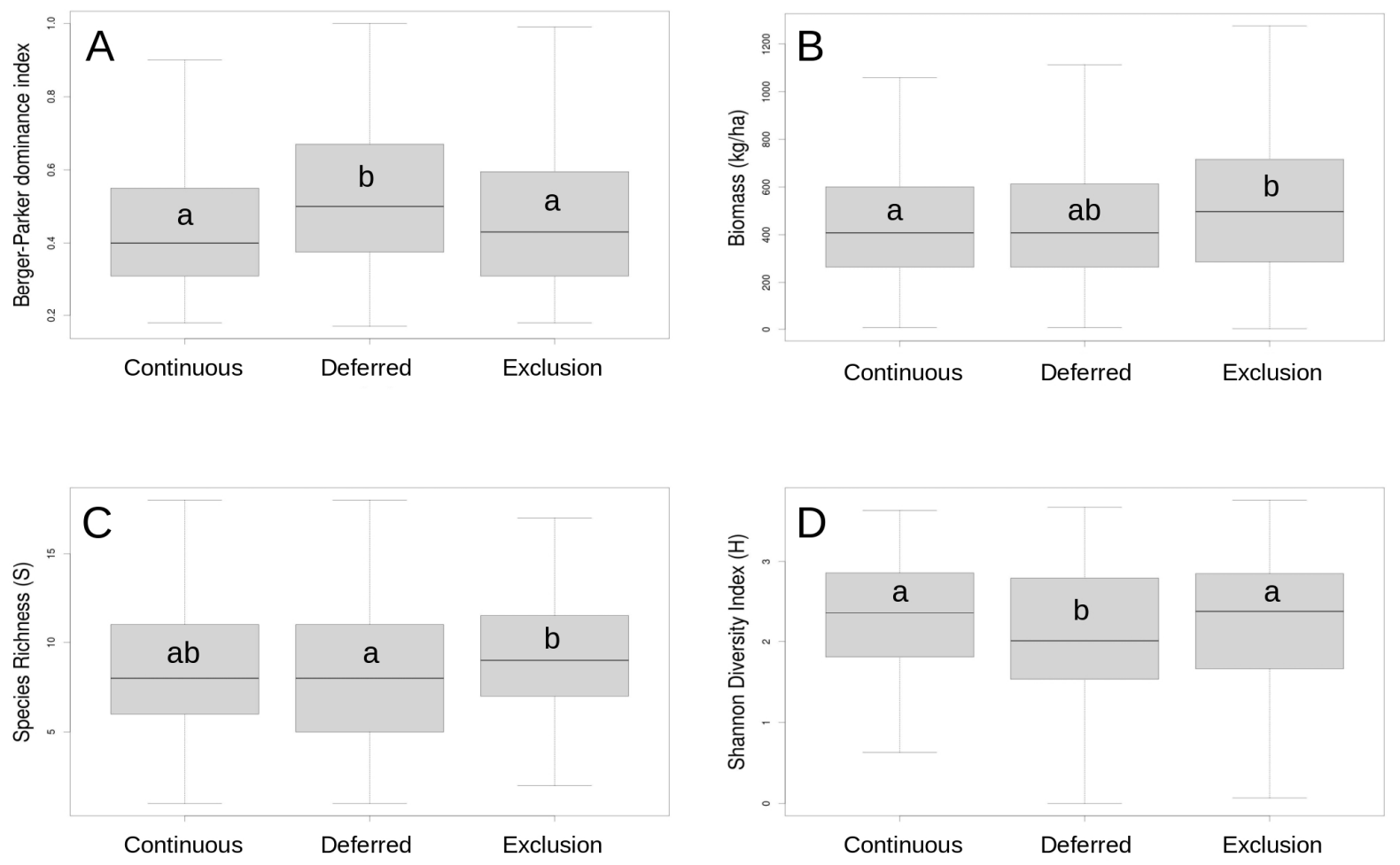

Figure 9. Box plots (means, standard deviations and ranges) of Berger-Parker dominance (A), biomass (B), species richness (C) and Shannon diversity (D) between continuous, deferred and excluded area grazing. Letters indicate groups showing significant differences according to Dunn's non-parametric test of variance with post-hoc comparison.

\section{Discussion}

This paper demonstrates that in Northern Chile, as in many arid areas around the world, inappropriate land managements derived from colonial period, overgrazing and a reduction in rainfall by climate change are the main causal factors of desertification [14,38]. Our results complement previous researches that attribute this process to the expansion of AL species introduced by Spanish conquerors [22,23]. AL plants are not well adapted to these arid environments [69] because in their area of origin annual rainfall exceeds $500 \mathrm{~mm}$. This is far from the average precipitation in CEALC area [10]. During the study period, only one extreme precipitation event approached the optimum rainfall value for AL species. This was in 1997 during a particularly low ENSO when $447.5 \mathrm{~mm}$ of precipitation was recorded. Despite the higher water requirements of the AL species respect to others, their propagation capacity is much higher than NT and EN species, both by vegetative methods and by seed. Therefore, during wet years these species would expand so much that they would compensate for their lesser adaptation to dry environmental conditions. On the other hand, we should not forget that AL species are more resistant to overgrazing than NT and EN species [7]. This is due to both their high levels of antinutritive compounds [70,71], higher seed production and faster vegetative growth [72]. These seeds, when left in the soil, would act as a reservoir that favors pulse expansion during wet years. Moreover, AL Spanish grassland species had coevolved together with ruminants during millennia [73]. In fact, AL plants have developed propagation systems based on endozoochory and epizoochory [74] that are very different to the autochory and allochory dispersion mechanism common in arid rangelands [75]. In this sense, it is very possible that the criollo goats are favoring the AL species by transferring their seeds either in their wool or through their feces. Further work should analyze this point by assessing 
these dispersal mechanisms that are common in the areas of origin of the AL species. By all these considerations, AL and AU species (both NT and EN) are not competitors even showing positive interactions. A possible explanation of this unexpected symbiotic effect is related to the higher growth rates of AL species during wet years. This could increase the levels of dry biomass and therefore soil nutrients that will be used by NT and EN species during the following dry years [76]. This theory is supported by certain studies that show a reduction in competence and more intense symbiotic relationships between lifeforms when the aridity increases [77]. Other studies relate a higher radiation in life-forms with an increment in the climate variability [75]. In this sense, the theory of ecological stability explains that under intense interannual climatic oscillations, local species decrease competence and increase symbiotic relationships for a joint benefit on the whole grassland community [78-80]. This theory is concordant with the positive correlations, observed in this study, between AL, NT and EN species. In contrast, AL group of species presents a dominance of annual grasses. This is other indicator of the higher adaptation of AL species to intense grazing conditions but it explains the less efficiency to drought conditions too.

Regard to the effect of grazing treatments, any significant difference was observed in AL species, whereas NT and EN plants show marked changes by its low resistance to grazing. Historically, Chilean flora of IV Region had evolved in absence of big ruminants with the exception of the Guanaco (Lama guanicoe Müller), which shows low densities in the area. Moreover, this mammal has a very marked seasonal grazing behavior in IV Region of Chile using high altitudes during spring and summer and low areas during winter. The author of [81] describes the diet of Guanaco in North Chile as highly selective. In contrast, goat grazing behavior is moderately selective for the study area [23]. Therefore, Chilean flora have evolved without the selective pressure of intense continuous grazing. This explains desertification in Northern Chile and not the competence with AL species. Another factor affecting desertification in North Chile is the free-ranging goat management. Some studies show that herds managed by shepherds not only desertify less, but also feed on a greater variety of forage resources [5]. We believe that this traditional free-ranging management can cause that goats feed even more on endemic and native plants.

The use of grazing exclusions have been emphasized as a good conservation practice for local species in many rangeland areas [82,83]. Exclusions show an intense recharge of seed bank that produces low inter-annual fluctuations in primary production $[84,85]$. Moreover, exclusions are an excellent strategy in terms of a larger general biodiversity conservation. In fact, this management system preserves many endangered species of flora and fauna [26]. Complementary to the use of exclusions, previous studies related deferred grazing with the increase in NT species [7]. In the Coquimbo area, deferred grazing results in the increase of the forage annual grass Bromus berterianus Colla. This species is adapted to the short period of grazing that the guanaco uses naturally [86-88]. In fact, deferred grazing, alone or combined with rotational grazing, appears as the best solution for Mediterranean rangelands [89]. Moreover, this management strategy limits soil erosion during the intense rainfall events by the higher abundance of plant biomass [26]. Moreover, deferred grazing (as exclusions) increases the seed bank levels too, causing smaller inter-annual fluctuations in grassland production [90]. This treatment enables farmers a better analysis of their future expenses in fodder and other supplements for ruminants [91].

From a methodological point of view, parameters such as diversity and dominance, are very useful for testing the effect of grazing management. In this sense, Berger-Parker's dominance is a good indicator of changes in AL species [7] increasing during overgrazing [92-94]. Other studies consider $\mathrm{H}^{\prime}$ and $\mathrm{S}$ as good indicators in semiarid rangelands [95]. However, in arid environments of North Chile $\mathrm{H}^{\prime}$ and $\mathrm{S}$ do not show significant changes according to grazing management.

Since an agroecological approach, it is very important to find strategies of compatibility between farmers' needs and nature conservation for these semiarid areas [96,97]. In this sense, a network of exclusions located in the main types of ecosystems of the IV Region 
of Chile could decrease the loss of natural taxa by overgrazing. Combining this network with deferred grazing would be possible to increase the sustainable incomes of rural areas and simultaneously guarantee conservation of natural resources. Moreover, this strategy have positive effects of carbon footprint of rangelands [98]. All these aspects are relevant in order to put in value one of the most degraded semiarid areas in the world.

\section{Conclusions}

The unappropriated goat grazing management is one of the most relevant factors of desertification in Northern Chile. Moreover, climate change and biological invasion of alien grassland species contributes to an intense loss in biodiversity. Applying economic efforts on these last factors can have null effects. However, grazing management is partially a cultural question. In many areas of the world, a combination of deferred grazing and exclusions have permitted increasing the productivity of arid rangelands and simultaneously conserving wildlife species. In this sense, the present work clearly shows, across many years of sampling, that this grazing system is a valuable alternative for one of the areas under a stronger risk of desertification in the world.

Supplementary Materials: The following are available online at https: / www.mdpi.com/article/ 10.3390/ecologies2040020/s1, Document S1: Allochthonous, native and endemic species sampled at the Las Cardas Range Station (CEALC) during the study period and spatial location of grazing exclusions.

Funding: This research has been possible through successive grants of the CEXECI (Center for Cooperation with South-America of Extremadura region, Spain) in 1994, the Regional Government of Extremadura region (SW Spain) during 1994, 1996 and 1998 and the Spanish Minister of Education in 2002. We also want to thank to colleagues of the University of Chile, Patricio Azócar, Sergio Lailhacar, Alfredo Olivares and Claudia Torres for your assistance during all these years. Rodomiro Osorio of the University of La Serena give valuable taxonomic information on native and endemic species. This paper was revised in term of English spelling by Pedro Delgado C2 Cambridge level expert.

Conflicts of Interest: The author declares no conflict of interest.

\section{References}

1. Burrell, A.L.; Evans, J.P.; De Kauwe, M.G. Anthropogenic climate change has driven over 5 million $\mathrm{km}^{2}$ of drylands towards desertification. Nat. Commun. 2020, 11, 3853. [CrossRef]

2. Akhtar-Schuster, M.; Schmiedel, U.; Jürgens, N. Biodiversity and Desertification. In Global Change: Enough Water for All? Lozán, J.L., Grassl, H., Hupfer, P., Menzel, L., Schönwiese, C.D., Eds.; Wissenschaftliche Auswertungen: Hamburg, Germany, 2007; pp. 224-226.

3. Zhang, R.; Jinsong, W.; Shuli, N. Toward a sustainable grazing management based on biodiversity and ecosystem multifunctionality in drylands. Curr. Opin. Environ. Sustain. 2021, 48, 36-43. [CrossRef]

4. López, B.C.; Rodríguez, R.; Gracia, C.A.; Sabaté, S. Climatic signals in growth and its relation to ENSO events of two Prosopis species following a latitudinal gradient in South America. Glob. Chang. Biol. 2006, 12, 897-906. [CrossRef]

5. Müller, F.L.; Samuels, M.I.; Cupido, C.F.; Swarts, M.B.V.; Hattas, D.; Morris, C.; Cyster, L.F.; Boatwright, J.S.; Amary, N.M. The impacts of season and livestock management strategy on the quality of diets selected by goats and sheep in the semi-arid rangelands of Namaqualand, South Africa. Afr. J. Range Forage Sci. 2019, 36, 1-10. [CrossRef]

6. El Aich, A.; Waterhouse, A. Small ruminants in environmental conservation. Small Rumin. Res. 1999, 34, 271-287. [CrossRef]

7. Azócar, P.; Patón, D. Influencia del sistema de pastoreo y de la variabilidad interanual sobre la biodiversidad del pastizal mediterráneo árido de la IV Región de Chile. In Proceedings of the 49th Symposium of the Agronomic Society of Chile (SACH), Santiago, Chile, 30 November-3 December 1998.

8. Bahre, C.J. Destruction of the Natural Vegetation of North-Central Chile; University of California Publications in Geography: Berkeley, CA, USA, 1979; Volume 23, pp. 1-118.

9. Salinas, C.X.; Mendieta, J. Mitigation and adaptation investments for desertification and climate change: An assessment of the socioeconomic return. Mitig. Adapt. Strateg. Glob. Chang. 2013, 18, 659-672. [CrossRef]

10. Azócar, P.; Lailhacar, S. Bases ecológicas para el desarrollo de la zona de clima mediterráneo árido de Chile. Terra Arida 1990, 8 , 221-301.

11. Kiringe, J.; Okello, M.M. Degradation of Rangelands: Causes, Ecological, Wildlife Conservation and Socio-Economic Implications; Nova Science Publishers: New York, NY, USA, 2010. 
12. Bedunah, D.J.; Angerer, J.P. Rangeland degradation, poverty, and conflict: How can rangeland scientists contribute to effective responses and solutions? Rangel. Ecol. Manag. 2012, 65, 606-612. [CrossRef]

13. Thokchom, B.; Qiu, P.; Singh, P.; Iyer, P. Water Conservation in the Era of Global Climate Change; Elsevier: New Delhi, India, 2021.

14. O'Connor, D.; Ford, D. Increasing the effectiveness of the "Great Green Wall" as an adaptation to the effects of climate change and desertification in the Sahel. Sustainability 2014, 6, 7142-7154. [CrossRef]

15. Squeo, F.A.; Aravena, R.; Aguirre, E.; Pollastri, A.; Jorquera, C.B.; Ehleringer, J.R. Groundwater dynamics in a coastal aquifer in north-central Chile: Implications for groundwater recharge in an arid ecosystem. J. Arid Environ. 2006, 67, 240-254. [CrossRef]

16. Holmgren, M.; López, B.C.; Gutiérrez, J.R.; Squeo, F.A. Herbivory and plant growth rate determine the success of El Niño Southern Oscillation-driven tree establishment in semiarid South America. Glob. Chang. Biol. 2006, 12, 2263-2271. [CrossRef]

17. Torres, R.; Squeo, F.A.; Jorquera, C.; Aguirre, E.; Ehleringer, J.R. Evaluación de la capacidad estacional de utilizar eventos de precipitación en tres especies de arbustos nativos de Chile con distintos sistemas radiculares. Rev. Chil. De Hist. Nat. 2002, 75, 737-749. [CrossRef]

18. Contreras, D.; Azocar, P.; Covarrabias, G.; Soto, G. Use of Forage Shrubs in the Arid-Land of Chile; General Technical Report INT-172; US Department of Agriculture, Forest Service: Washington, DC, USA, 1984; pp. 237-242.

19. Tracol, Y.; Gutiérrez, J.R.; Squeo, F.A. Plant Area Index and microclimate underneath shrub species from a Chilean semiarid community. J. Arid Environ. 2011, 75, 1-6. [CrossRef]

20. Thibault, K.M.; Ernest, S.K.M.; White, E.P.; Nrown, J.H.; Goheen, J.R. Long-term insights into the influence of precipitation on community dynamics in desert rodents. J. Mammal. 2010, 91 Pt 4, 787-797. [CrossRef]

21. Dotterweich, M. The history of human-induced soil erosion: Geomorphic legacies, early descriptions and research, and the development of soil conservation. A global synopsis. Geomorphology 2013, 201, 1-34. [CrossRef]

22. Azócar, P. Hábitos de pastoreo y de consumo de especies forrajeras del ganado caprino en zonas áridas. Av. Prod. Anim. 1987, 12, 3-9.

23. Azócar, P.; D-Herbes, J.M.; Díaz, J. Estudio de sistemas de pastoreo con caprinos para el secano árido de la IV Región de Coquimbo. 1: Dieta e índices de aceptabilidad relativa de arbustos. Av. Prod. Anim. 1987, 12, 35-47.

24. Shackleton, C.M. Comparison of plant diversity in protected and communal lands in the Bushbuckridge low veld savanna, South Africa. Biol. Conserv. 2000, 94, 273-285. [CrossRef]

25. Stafford-Smith, D.M.; Campbell, B.D.; Archer, S.; Steffen, W. Pasture and Rangeland Network: An Implementation Plan. In Global Change and Terrestrial Ecosystems; Report no 3; CSRIO, Division of Wildlife and Ecology: Canberra, Australia, 1995.

26. Holecheck, J.L.; Pieper, R.D.; Herbel, C.H. Range Management. Principles and Practices; Pearson: New York, NY, USA, 2011.

27. Al-Rowaily, S.L.; El-Bana, M.I.; Al-Bakre, D.A.; Assaeed, A.M.; Hegazy, A.K.; Ali, M.A. Effects of open grazing and livestock exclusion on floristic composition and diversity in natural ecosystem of Western Saudi Arabia. Saudi J. Biol. Sci. 2015, 22, 430-437. [CrossRef]

28. Fabio, G.; Merlo, M.; Tosi, V. Silvicultural management in maintaining biodiversity and resistance of forests in Europe-the Mediterranean Region. J. Environ. Manag. 2003, 67, 67-76. [CrossRef]

29. Peacock, J.M.; Ferguson, M.E.; Alhadrami, G.A.; McCann, I.R.; Al Hajoj, A.; Saleh, A.; Karnik, R. Conservation through utilization: A case study of the indigenous forage grasses of the Arabian Peninsula. J. Arid Environ. 2003, 54, 15-28. [CrossRef]

30. Polley, H.W.; Johson, H.B.; Tischler, C.R. Woody invasion of grasslands: Evidence that $\mathrm{CO}_{2}$ enrichment indirectly promotes establishment of Prosopis Glandulosa. Plant. Ecol. 2003, 164, 85-94. [CrossRef]

31. Na, Y.; Li, J.; Hoshino, B.; Bao, S.; Qin, F.; Myagmartseren, P. Effects of Different Grazing Systems on Aboveground Biomass and Plant Species Dominance in Typical Chinese and Mongolian Steppes. Sustainability 2018, 10, 4753. [CrossRef]

32. Li, Y.; Zhao, X.; Chen, Y.; Luo, Y.; Wang, S. Effects of grazing exclusion on carbon sequestration and the associated vegetation and soil characteristics at a semi-arid desertified sandy site in Inner Mongolia, Northern China. Can. J. Soil Sci. 2012, 92, 807-819. [CrossRef]

33. Zeng, H.; Wu, B.; Zhang, M.; Zhang, N.; Elnashar, A.; Zhu, L.; Zhu, W.; Wu, F.; Yan, N.; Liu, W. Dryland ecosystem dynamic change and its drivers in Mediterranean region. Curr. Opin. Environ. Sustain. 2021, 48, 59-67. [CrossRef]

34. Ormazábal, C.S. Silvopastoral systems in arid and semiarid zones of Northern Chile. Agrofor. Syst. 1991, 14 Pt 3, $207-217$. [CrossRef]

35. Fuentes, N.; Pauchard, A.; Sánchez, P.; Esquivel, J.; Marticorena, A. A new comprehensive database of alien plant species in Chile based on herbarium records. Biol. Invasions 2013, 15, 847-858. [CrossRef]

36. Collier, S.; Sater, W.F. A History of Chile 1802-2002; Cambridge University Press: Cambridge, UK, 2004; 454p.

37. Squeo, F.A.; Loayza, A.P.; López, R.P.; Gutiérrez, J.A. Vegetation of Bosque Fray Jorge National Park and its surrounding matrix in the Coastal Desert of north-central Chile. J. Arid Environ. 2016, 126, 12-22. [CrossRef]

38. Menestrey-Schwieger, D.A.; Mbidzo, M. Socio-historical and structural factors linked to land degradation and desertification in Namibia-s former Herero 'homelands'. J. Arid Environ. 2020, 178, 104151. [CrossRef]

39. Montecinos, S.; Gutiérrez, J.R.; López-Cortés, F.; López, D. Climatic characteristics of the semi-arid Coquimbo Region in Chile. J. Arid Environ. 2016, 126, 7-11. [CrossRef]

40. Verbist, K.; Robertson, A.W.; Cornelis, W.M.; Gabriels, D. Seasonal predictability of daily rainfall characteristics in central northern Chile for dry-land management. J. Appl. Meteorol. Climatol. 2010, 49, 1938-1955. [CrossRef] 
41. Poveda, G.; Waylen, P.R.; Pulwarty, R.S. Annual and inter-annual variability of the present climate in northern South America and southern Mesoamerica. Paleogeogr. Paleoclimatol. Paleoecol. 2006, 234, 3-27. [CrossRef]

42. Azócar, P.; Patón, D.; Osorio, R.; Le Floc'h, E. Efecto de la poda sobre la produción de forraje del Rumpiato (Bridgesia incisifolia, Bert ex Cambess). Av. Prod. Anim. 2001, 1-2, 97-106.

43. Schulz, N.; Aceituno, P.; Richter, M. Phytogeographic divisions, climate change and plant dieback along the coastal desert of Northern Chile. Erdkunde 2011, 65, 169-187. [CrossRef]

44. Soto, M.V.; Märker, M.; Arriagada, J.; Castro, C.P.; Rodolfi, G. Evaluación de la amenaza natural en ambiente semiárido, sustentada en la geomorfología y el modelamiento de índices topográficos. Salamanca, Región de Coquimbo, Chile. Investig. Geogr. 2010, 42, 19-36. [CrossRef]

45. Rojo, H. Efecto del Sistema y de la Época de Pastoreo sobre la Disponibilidad de Forraje del Incienso (Flourensia thurifera (Mol.) DC.); Memoria de Título Profesional de Ingeniero Agrónomo; Facultad de Ciencias Agrarias y Forestales, Universidad de Chile: Santiago, Chile, 1989.

46. Díaz, J. Recursos Forrajeros y Comportamiento del Ganado Caprino en dos Localidades del Secano Mediterráneo Árido; Memoria de Título Profesional de Ingeniero Agrónomo; Facultad de Ciencias Agrarias y Forestales, Universidad de Chile: Santiago, Chile, 1988.

47. Squeo, F.A.; Martínez, K.; Letelier, L.; Rentería, L.; Figueroa, M. Libro Rojo de la Flora Nativa y de los Sitios Prioritarios para su Conservación, Región de Coquimbo; Ediciones Universidad de La Serena: La Serena, Chile, 2008; 451p.

48. Rojas, P.; González, M.; Benedetti, S.; Yates, P.; Sotomayor, A.; Dube, F. Silvopastoral Systems in Arid and Semiarid Zones of Chile. In Silvopastoral Systems in Southern South America; Peri, P.L., Dube, F., Varella, A., Eds.; Springer International Publishing: Cham, Switzerland, 2016; pp. 169-181.

49. Patón, D.; Osorio, R.; Le Floc' h, P.; Azócar, P.; Portilla, L. Analysis of a multivariate model for detecting goat overbrowsing in the arid zone of Northern Chile. Application to Bridgesia incisifolia (Bert ex Cambess) shrublands. J. Arid Environ. 1999, 43, 197-204. [CrossRef]

50. Azor, P.J.; Monteagudo, L.V.; Luque, M.; Tejedor, M.T.; Rodero, E.; Sierra, I.; Herrera, M.; Rodero, A.; Arruga, M.V. Phylogenetic relationships between Spanish goat breeds. Anim. Genet. 2005, 36, 423-425. [CrossRef] [PubMed]

51. Legendre, P.; Legendre, L. Numerical Ecology; Elsevier: Amsterdam, The Netherlands, 2012; 1006p.

52. Sutherland, W.J. Ecological Census Techniques: A Handbook; Cambridge University Press: Cambridge, UK, 2006; 432p.

53. Poissonet, P.S.; Daget, P.M.; Poissonet, J.A.; Long, G.A. Rapid point survey by bayonet blade. J. Range Manag. 1972, $25,313$. [CrossRef]

54. Greig-Smith, P. Quantitative Plant Ecology; Academic Press: New York, NY, USA, 1983; 359p.

55. Balzter, H.; Braun, P.; Köhler, W. Detection of Spatial Discontinuities in Vegetation Data by a Moving Window Algorithm. In From Data to Knowledge: Theoretical and Practice Aspects of Classification, Data Analysis and Knowledge Organization; Gaul, W., Pfeifer, D., Eds.; Springer: Berlin, Germany, 1995; pp. 243-252.

56. Buyolo, T.; Patón, D.; Fernández, 1.; Cabezas, J. Estimación de la biomasa de pastos mediterráneos mediante modelos de algoritmos genéticos sobre medidas de point-quadrat. In XLIV Reunión Científica de la SEEP. Pastos y Ganadería Extensiva; SEEP: Salamanca, Spain, 2004; pp. 105-109.

57. Patón, D.; Bermejo, L.; Camacho, A.; De Nascimento, L.; Bethencourt, L.; Mata, J. A biomass prediction model for grasslands of Canary Islands. In Grassland Science in Europe. Sustainable Grassland Productivity; EGF: Badajoz, Spain, 2006 ; pp. 523-525.

58. Magurran, A.E. Measuring Biological Diversity; Blackwell Publishing: Oxford, UK, 2013; 266p.

59. Mac Nally, R. Multiple regression and inference in ecology and conservation biology: Further comments on identifying important predictor variables. Biodivers. Conserv. 2002, 11, 1397-1401. [CrossRef]

60. Chevan, A.; Sutherland, M. Hierarchical Partitioning. Am. Stat. 1991, 45, 90-96.

61. Jobson, J.D. Applied Multivariate Data Analysis. Volume I: Regression and Experimental Design; Springer: Berlin, Germany, 1991; 544p.

62. Hatt, B.E.; Fletcher, T.D.; Walsh, C.J.; Taylor, S.L. The influence of urban density and drainage infrastructure on the concentrations and loads of pollutants in small streams. Environ. Manag. 2004, 34, 112-124. [CrossRef]

63. Walsh, C.J.; Papas, P.J.; Crowther, D.; Sim, P.T.; Yoo, J. Stormwater drainage pipes as a threat to a stream-dwelling amphipod of conservation significance, Austrogammarus australis, in South-Eastern Australia. Biodivers. Conserv. 2004, 13, 781-793. [CrossRef]

64. Olea, P.; Mateo-Tomás, P.; De Frutos, A. Estimating and modeling bias of the Hierarchical Partitioning public-domain software: Implications in environmental management and conservation. PLOS ONE 2010, 5, 1-7. [CrossRef]

65. Mac Nally, R. Regression and model building in conservation biology, biogeography and ecology: The distinction between and reconciliation of predictive and explanatory models. Biodivers. Conserv. 2000, 9, 655-671. [CrossRef]

66. Oliver, I.; Mac Nally, R.; York, A. Identifying performance indicators of the effects of forest management on ground-active arthropod biodiversity using hierarchical partitioning and partial canonical correspondence analysis. For. Ecol. Manag. 2000, 139, 21-40. [CrossRef]

67. Logan, M. Biostatistical Design and Analysis Using R; Wiley-Blackwell: Oxford, UK, 2010; 546p.

68. R Core Team. R: A Language and Environment for Statistical Computing; R Foundation for Statistical Computing: Vienna, Austria, 2020.

69. Holzapfel, C.; Tielbörger, K.; Parag, H.A.; Kigel, J.; Sternberg, M. Annual plant-shrub interactions along an aridity gradient. Basic Appl. Ecol. 2006, 7, 268-279. [CrossRef] 
70. Patón, D. Elaboration of a multivariate model for the determination of the metabolizable energy of Mediterranean bushes based on chemical parameters. J. Arid Environ. 2003, 53, 271-280. [CrossRef]

71. Patón, D.; Salvado, A.; Venegas, F. Relationships between metabolizable energy and chemical parameters from forest fruits using a parallel genetic algorithm worldwide model. In New Research in Forest Ecology; Scaggs, A.K., Ed.; Nova Science Publishers: New York, NY, USA, 2007; pp. 129-140.

72. Hohnwald, S.; Trautwein, J.; Camarão, A.P.; Wollny, C.B. Relative palatability and growth performance of capoeira species as supplementary forages in the NE-Amazon. Agric. Ecosyst. Environ. 2016, 218, 107-115. [CrossRef]

73. Montserrat, P.; Fillat, F. The systems of grassland management in Spain. In Managed Grasslands; Breymeyer, A., Ed.; Elsevier Science Publishers: Amsterdam, The Netherlands, 1990; pp. 37-70.

74. Malo, J.E.; Suarez, F. The dispersal of a dry-fruited shrub by red deer in a Mediterranean ecosystem. Ecography 1998, 21, 204-211. [CrossRef]

75. Van Rheede, K.; Van Rhooyen, M.W. Dispersal Biology of Desert Plants; Springer: Berlin/Heidelberg, Germany, 1999.

76. Squeo, F.A.; Olivares, N.; Olivares, S.; Pollastri, A.; Aguirre, E.; Aravena, R.; Jorquera, C.; Ehleringer, J.R. Functional groups in North Chilean desert shrubs species based on the water sources used. Gayana Bot. 1999, 56, 1-15.

77. De Soyza, A.G.; Van Zee, J.W.; Whitford, W.G.; Neale, A.; Tallent-Hallsel, N.; Herrick, J.E.; Havstad, K.M. Indicators of Great Basin rangeland health. J. Arid Environ. 2000, 45, 289-304. [CrossRef]

78. Tilman, D.; Wedin, D.; Knops, J. Productivity and sustainability influenced by biodiversity in grassland ecosystems. Nature 1996, 379, 718-720. [CrossRef]

79. Tilman, D.; Knops, J.; Wedin, D.; Reich, P.; Ritchie, M.; Siemann, E. The influence of functional diversity and composition on ecosystem processes. Science 1997, 277, 1300-1302. [CrossRef]

80. Tilman, D.; Reich, P.B.; Knops, J.M.H. Biodiversity and ecosystem stability in a decade-long grassland experiment. Nature 2006, 441, 629-631. [CrossRef] [PubMed]

81. Cepeda, J. Geoecología de los Andes Desérticos. La Alta Montaña del Valle de Elqui; Ediciones Universidad de la Serena: La Serena, Chile, 2006; 551p.

82. Pucheta, E.; Vendramini, F.; Cabido, M.; Díaz, S. Estructura y funcionamiento de un pastizal de montaña bajo pastoreo y su respuesta luego de la exclusión. Rev. Fac. Agron. La Plata 1998, 103, 77-92.

83. Costello, D.A.; Lunt, I.A.; Williams, J.E. Effects on invasion by the indigenous shrub Acacia sophorae on plant composition on coastal grasslands in south-eastern Australia. Biol. Conserv. 2000, 96, 113-121. [CrossRef]

84. Homewood, K.M. Policy, environment and development in Africa rangelands. Environ. Sci. Policy 2004, 7, 125-143. [CrossRef]

85. Allen-Diaz, B.; Jackson, R.D. Grazing effects on spring ecosystem vegetation of California-s hardwood rangelands. J. Range Manag. 2000, 53, 215-220. [CrossRef]

86. Patón, D.; Muñoz, A.; Tovar, J. Impacto medioambiental del vacuno Retinto sobre pastizales mediterráneos. In Proceedings of the I Congreso Internacional de Veterinaria y Medioambiente, Cáceres, Spain, 24-26 April 1997; pp. 482-489.

87. Patón, D.; Muriel, J.; Nuñez, J. Determination of population diversity using Von Bertalanffy-s regression model. Application to cumulative sampling sizes of grazing grasslands by Retinto cattle in Extremadura region (SW Spain). In Proceedings of the First International Conference on Applied Science and the Environment (ASE 98), Cádiz, Spain, 5-8 October 1998; pp. 23-24.

88. Patón, D.; Muriel, J.; Tovar, J. Cambios en la vegetación después de la exclusión de áreas pastoreadas por Retinto en Extremadura. In Actas del Congreso Europeo de Agricultura Sostenible en Ambientes Mediterráneos, Proceedings of the Congreso Europeo de Agricultura Sostenible en Ambientes Mediterráneos, Badajoz-Mérida, Spain, 22-25 March 1999; Consejería de Agricultura y Comercio, Junta de Extremadura: Merida, Spain, 1999; pp. 152-156.

89. Volesky, J.D.; De Achaval, F.; Ellis, W.C.; Kothmann, M.M.; Horn, F.P.; Phillips, W.A.; Coleman, S.W. A comparison of frontal, continuous and rotational grazing systems. J. Range Manag. 1994, 47, 210-214. [CrossRef]

90. Duru, M.; Hubert, B. Management of grazing systems: From decision and biophysical models to principles for action. In Sustainable Agriculture; Litchfouse, E., Navarrete, M., Debaeke, P., Véronique, S., Alberola, C., Eds.; Springer: Amsterdam, The Netherlands, 2009; pp. 823-842.

91. Whitson, R.E.; Heitschmidt, R.K.; Kothmann, M.M.; Lundgren, G.K. The impact of grazing systems on the magnitude and stability of ranch income in the rolling plains of Texas. J. Range Manag. 1982, 35, 526-532. [CrossRef]

92. Alados, C.L.; El Aich, A.; Papanastasis, V.P.; Ozbek, H.; Navarro, T.; Freitas, H.; Mihalis, V.; Larrosi, D.; Cabezudo, B. Change in plant spatial patterns and diversity along the successional gradient of Mediterranean grazing ecosystems. Ecol. Model. 2004, 180, 523-535. [CrossRef]

93. Alhamad, M.N. Ecological and species diversity of arid Mediterranean grazing land vegetation. J. Arid Environ. 2006, 66, 698-715. [CrossRef]

94. Bai, Y.; Abouguendia, Z.; Recmann, R.E. Relationship between plant species diversity and grassland condition. J. Range Manag. 2001, 54, 177-183. [CrossRef]

95. Adler, P.B.; Morales, J.M. Influence of environmental factors and sheep grazing on an Andean grasslands. J. Range Manag. 1999, 52, 471-480. [CrossRef]

96. Altieri, M.A. Agroecology: The science of natural resource management for poor farmers in marginal environments. Agric. Ecosyst. Environ. 2002, 1971, 1-24. [CrossRef] 
97. Aguilar, C.; Vera, R.; Allende, R.; Toro, P. Supplementation, stocking rates and economic performance of lamb production systems in the Mediterranean-type region of Chile. Small Rumin. Res. 2006, 66, 108-115. [CrossRef]

98. Gutiérrez-Peña, R.; Mena, Y.; Batalla, I.; Mancilla-Leytón, J.M. Carbon footprint of dairy goat production systems: A comparison of three contrasting grazing levels in the Sierra de Grazalema Natural Park (Southern Spain). J. Environ. Manag. 2019, 232, 993-998. [CrossRef] [PubMed] 